Web Site: https://jutq.utq.edu.iq/index.php/main

Email: journal@jutq.utq.edu.iq

\title{
Design and Implementation of Z-Wave Sniffer on TI-CC1125 \\ Transceiver
}

https://doi.org/10.32792/utq/utj/vol12/3/9

\section{Ali Kareem Abdulrazzaq Collage of Engineering / Thi-Qar University}

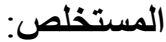

مقترح من خلال هذا البحث تنفيذ متحكم رئيسي بالمنزل الذكي بالاعتماد على تكنولوجيا الاتصال

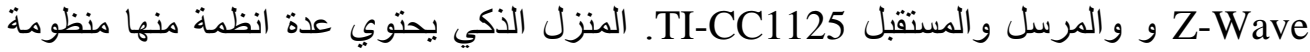

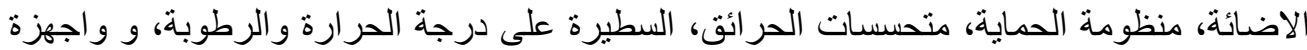
اخرى مربوطة عبر شبكة لا سلكية. بدلا من استخدام من متحكم منفصل لكل منظومة، نقترح في في هذا البحث تصميم منظومة تحكم رئيسية لعرض ومتابعة جميع المنظومات الفرعية من خلال استنشاق

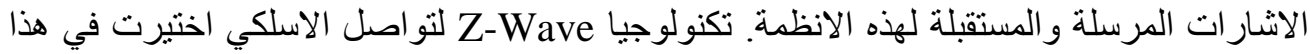
البحث. وحدة الارسال والاستقبال المستخدمة لهذا الغرض هي Instruments (TI)

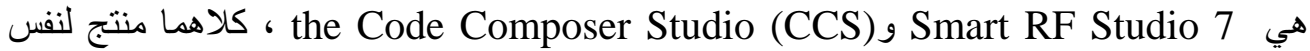
الثركة (TI). تعرض البيانات الملتقطة على الثاثة المثبتة على جهاز الاستلام فضلا عن عرضة كانة على الحاسوب بعد ربط الجهاز عبر وصلة UART و التي ممكن بعد ذللك معالجتها لانجاز وضيفة

\section{Abstract}

This paper proposed a new smart home master control system based on Zwave network and the TI-CC1125 transceiver. The smart home system includes lighting system, security system, smoke sensors, environment control and other equipment which are connected to a wireless communication network. Instead of having a specific controller for each system, in this paper we suggest having a master controller that monitor all systems status via sniffing their transceiver signals. Z-wave is the selected communication technology for this research. The Texas instrument lower power consumption transceiver (TI-CC1125) is used for this purpose in the sniffer mode of operation. Smart RF Studio 7 and the Code Composer Studio (CCS), both produced by Texas Instrument, are used for programming the Transceiver. The sniffed packets are displayed by the on-board LCD screen as well as the on PC application over UART interface, which can be processed later for a specific function. 


\section{University of Thi-Qar Journal Vol.12 No.3 SEP 2017 \\ Web Site: https://jutq.utq.edu.iq/index.php/main Email: journal@jutq.utq.edu.iq}

Keywords: Smart Home, Z-Wave, RX Sniff Mode, Wake on Radio, and CC1125 Transceiver.

\section{Introduction}

The receiver current is very important parameter, especially for the battery powered devices. Sniff Mode is a very efficient concept to reduce the RX current. The Sniffer is a device that eavesdrops the network traffic by grabbing the traveling information over the communication medium. In this mode, the device wakes up from the sleep state to RX and go back to sleep periodically with a defined duty cycle [1].

This concept is strongly enhanced by CC1125 Transceiver due to its short settling time. CC1125 Transceiver is produced by Texas Instruments, with operating frequency in the range of the Industrial, Scientific, and Medical (ISM) frequency band. Home automation become very popular in the recent years, to integrates electrical devices (i.e. Comfort Function, Security Function, Medical etc.) in a house with each other, this means, many devices working in the same closed area, however these devices are not sending and receiving signals all the time, therefore the RX Sniff Mode would be the best choice to monitor the signals transferred between different devices. One of the most powerful home automation technologies is the Z-Wave protocol, which is very well standardized by the International Telecommunication Union.

Z-Wave is low power wireless communication technology mainly used in home applications. Z-Wave oriented to interconnect many functions dealing with security, lighting, climate conditioning door locks etc. to perform automation on these functions [2].

\section{CC1125 Transceiver Evaluation Board}

This work is mainly implemented on the low power RF transceiver, CC1125 Transceiver Evaluation Board (TRXEB) produced by Texas Instruments. CC1125 is fully integrated transceiver chip for low power and high performance. Figure 1 shows the PCB top view that handles the Sub $1 \mathrm{GHz}$ transceiver in terms of $\mathrm{CC} 1125$ Transceiver, microcontroller and some other peripherals [3].

CC1125 Transceiver is mainly uses the Industrial, Scientific and Medical radio bands (164-192MHz, 274-320MHz, 410-480MHz and 820-960MHz.), 


\section{University of Thi-Qar Journal Vol.12 No.3 SEP 2017 \\ Web Site: https://jutq.utq.edu.iq/index.php/main Email: journal@jutq.utq.edu.iq}

in this project and according to the European regulations, the $820-960 \mathrm{MHz}$ has been considered [4,5]. CC1125 supports hardware packet handling features including data buffering, link quality indication, and automatic lowpower data receiving via Wake-On-Radio (WOR).

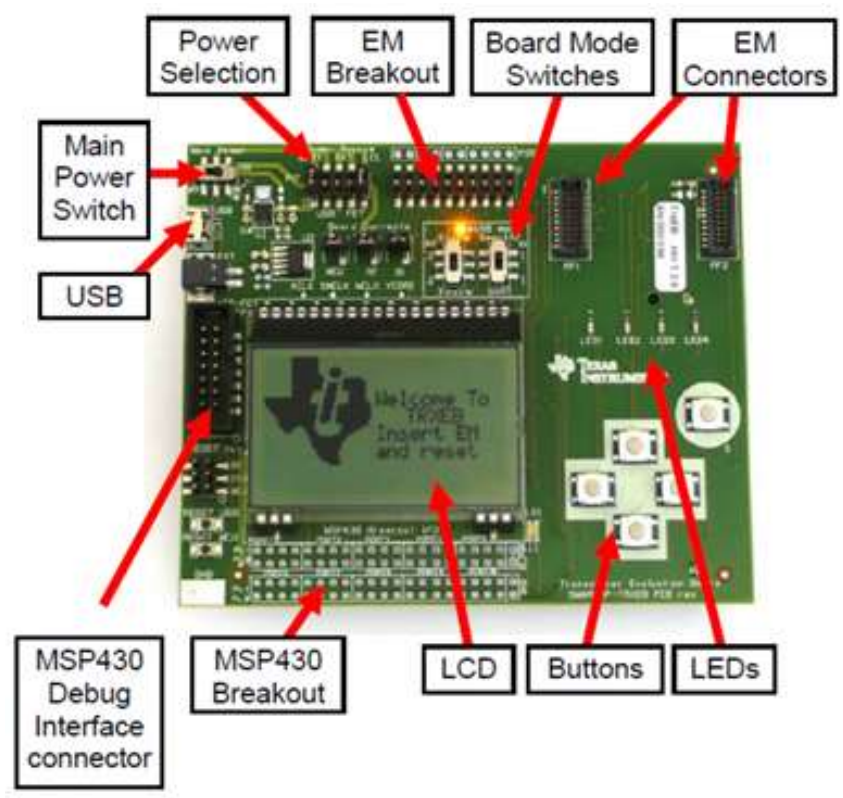

Figure 1: CC1125 Transceiver Evaluation Board with EM and LCD connected [3]

CC1125 supports hardware packet handling features including data buffering, link quality indication, and automatic low-power data receiving via Wake-On-Radio (WOR) [6].

\section{Sniffer Mode Theory}

The Sniffer Mode is especially needed in case it is not known when the transmitter sends a packet. This concept becomes more important for battery powered nodes, in which it is not required to be in RX mode all time, and it is sufficient to periodically wake-up from the sleeping mode and return to it if no valid packet is received. This periodic operation is adjusted by Wake-OnRadio feature [6,7].

\subsection{RX Sniff Mode Usage}

The normal RX Mode keeps the receiver always waiting for a packet to be sure that it receives the packet when the transmitter starts sending. In this 


\section{University of Thi-Qar Journal Vol.12 No.3 SEP 2017 \\ Web Site: https://jutq.utq.edu.iq/index.php/main \\ Email: journal@jutq.utq.edu.iq}

mode the transmitted packet doesn't require long preamble (4-bits is sufficient), figure 2 illustrates this mode [8].

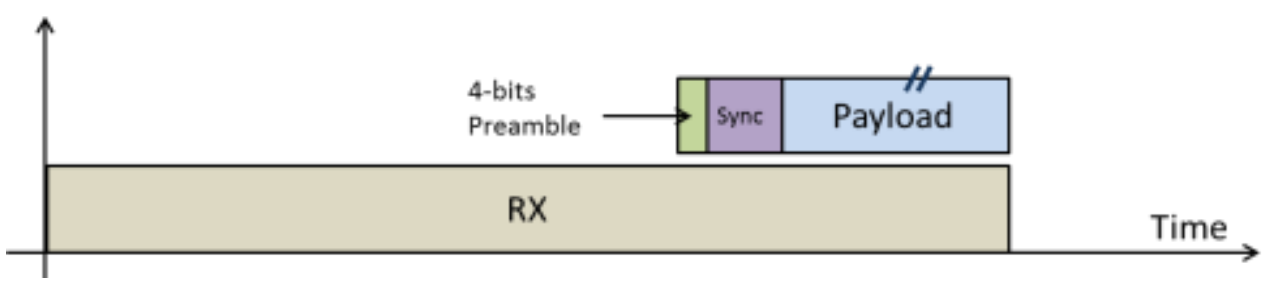

Figure 2: Ordinary RX Mode [8]

The transmitted packet requires longer preamble to be recognized by the receiver in the Sniff Mode, as it is important to receive 4-bits at least. Thereby the receiver can enter the sleeping mode and wake-up periodically, so that, and as it is illustrated in figure 3 the wake-up interval time is depending on the preamble length.

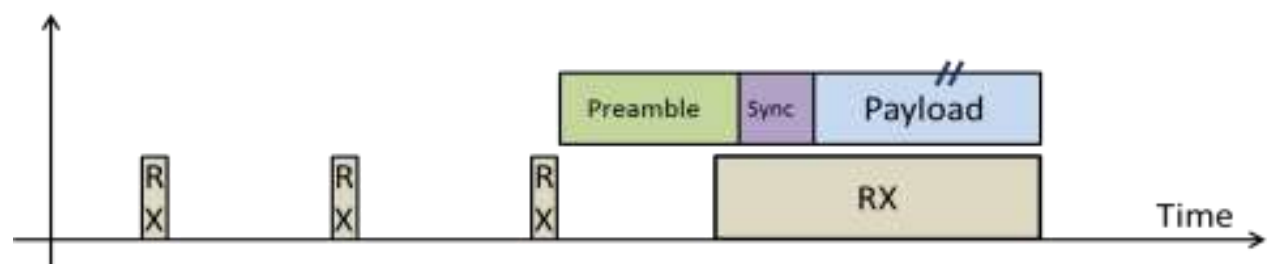

Figure 3: RX Sniff Mode [8]

\section{Sniffer Software Design for the Proposed System}

At first, the SmartRF Studio software tool has been used in RX Mode to find the suitable registers configurations of the CC1125 transceiver that match the Z-Wave RF PHY layer parameters. Then use these registers settings as a starting point to write the embedded code for designing the Sniffer using C language. The Code Composer Studio (CCS) is used as a development environment.

Z-Wave with $40 \mathrm{Kbps}$ data rate has been considered in this design as a source node, however, it is very well possible to use this design to sniff other Z-Wave devices packets after taking into account the differences in the PHY layer parameters (i.e. data rate, frequency, coding format, etc.). 


\section{University of Thi-Qar Journal Vol.12 No.3 SEP 2017 \\ Web Site: https://jutq.utq.edu.iq/index.php/main \\ Email: journal@jutq.utq.edu.iq}

\subsection{SmartRF Studio Configuration}

This section will cover the registers values selecting techniques, which can be divided into two parts. The first part includes the parameters that depend on the Z-Wave standard specifications. The second part deals with the unknown parameters of the transmitted frame which may be different from device to another.

\subsubsection{SmartRF Configuration in RX Mode}

Z-Wave technology has standard parameters that describe the PHY layer specifications. These specifications have to be considered during the configuration of the SmartRF to receive a correct packet. Figure 4 shows the first step configuration.

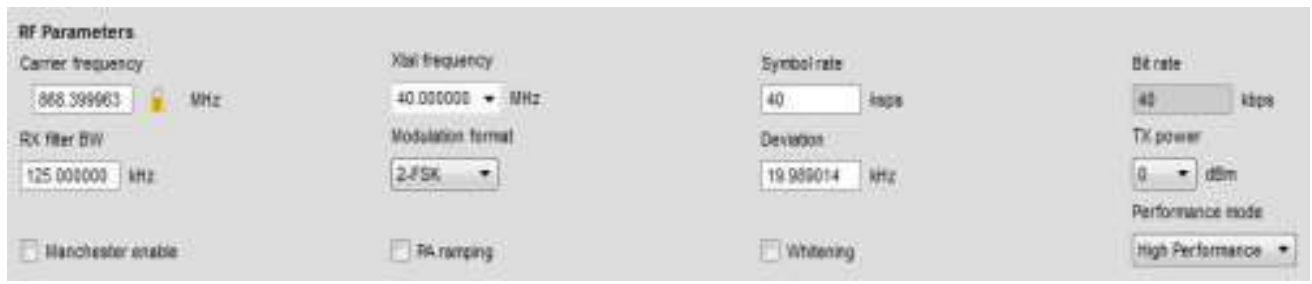

Figure 4: SmartRF Studio configuration

After configuring the SmartRF Studio with these values, it is very easily to read the value of the register(s) for every configured field. Table 1 shows the radio requirements for $40 \mathrm{Kbps}$ data rate packet and the corresponding registers values. It is important to note that some of the registers may correlate the setting of different parameters, where each register consist of subfields each field defined the specific parameter.

As a result, it is important to finish the entire configuration with the SmartRF Studio before considering the value of the registers as final values and copy it to the next design step.

\subsubsection{Configuration of Other Registers to Receive Correct Packet}

Configuring the SmartRF Studio with the given standards Z-Wave RF parameters is not enough to receive a correct packet, therefore some more registers have to be configured first to receive the correct packet (transmitted packet from the source node). 
University of Thi-Qar Journal Vol.12 No.3 SEP 2017

Web Site: https://jutq.utq.edu.iq/index.php/main

Email: journal@jutq.utq.edu.iq

Table 1: Registers configuration according to Z-Wave specifications

\begin{tabular}{|l|l|l|}
\hline $\begin{array}{l}\text { Z-Wave Radio } \\
\text { Specification }\end{array}$ & $\begin{array}{l}\text { Corresponding } \\
\text { Register in CC1125 }\end{array}$ & Register Value \\
\hline Frequency= 868.4MHz & $\begin{array}{l}\text { FREQ2 } \\
\text { FREQ1 } \\
\text { FREQ0 }\end{array}$ & $\begin{array}{l}\text { 0x56 } \\
\text { oxD7 } \\
\text { 0x0A }\end{array}$ \\
\hline Data Rate= 40Kbps & DRATE2 & 0x90 \\
& DRATE1 & $\begin{array}{l}\text { DR62 } \\
0 x 4 E\end{array}$ \\
\hline Coding type: NRZ & MDMCFG1 & 0x46 \\
\hline Modulation Format: FSK & SYNC_CFG1 & $\begin{array}{l}\text { 0x0B } \\
\text { MODCFG_DEV_E }\end{array}$ \\
\hline $\begin{array}{l}\text { Frequency Deviation }= \\
\text { 20KHz }\end{array}$ & $\begin{array}{l}\text { DEVIATION_M } \\
\text { MODCFG_DEV_E }\end{array}$ & $\begin{array}{l}\text { 0x06 } \\
\text { 0x05 }\end{array}$ \\
\hline
\end{tabular}

One of the important parameters to be configured is the sync word. Without choosing the write Sync Word it is not possible to receive the packet and read it from the First in First out (FIFO). The key point here is to configure the Sync Word registers SYNCx of (where $\mathrm{x}$ is from 1 to 4 ) the CC1125 transceiver with the preamble value; thereby the receiver will receive the whole packet including the preamble. Table 2 shows the value of the Sync Word registers values that have been used.

The bandwidth is set according to Carson's rule, which states that the bandwidth frequency is larger than or equal to the double of the sum of the data rate and the frequency deviation [10].

In this design the data rate is $40 \mathrm{Kbps}$ and the deviation is $20 \mathrm{KHz}$, therefore the BW can be chosen to be larger or equal to $120 \mathrm{KHz}$. The nearest value offered by the SmartRF Studio is $125 \mathrm{KHz}$. Up to this level of the configuration, and after run the SmartRF Studio in Packet RX testing mode, it is possible to receive packets. However, the setting of the other registers is 


\section{University of Thi-Qar Journal Vol.12 No.3 SEP 2017 \\ Web Site: https://jutq.utq.edu.iq/index.php/main \\ Email: journal@jutq.utq.edu.iq}

tunable until receiving the correct packet by comparing the received data with the originally transmitted packet (assuming that the original packet is known).

Table 2: Sync Word registers values

\begin{tabular}{|c|c|}
\hline Register & Value \\
\hline SYNC3 & 0xAA \\
\hline SYNC2 & 0xAA \\
\hline SYNC1 & 0xAA \\
\hline SYNC0 & 0xAA \\
\hline
\end{tabular}

\subsubsection{Evaluation the Received Packet}

Here the received packet is evaluated and compared with the transmitted one to make sure that the received packet carries the expected information from the source node. The transmitted packet from the Z-Wave device is shown in figure 5.

\section{$016 \mathrm{~B} \mathrm{A0} 4 \mathrm{D} 1 \mathrm{D} 4102$ OD 1C 20010016}

Figure 5: Transmitted packet from Z-Wave device

According to the setting of registers that described in the previous sections, the received packet is shown in figure 6 .

AA AA AA AA AA AA AA AA AA AA AA AO FF E 945 FB 2 E $2 B$ EF DF 2 E $3 D$ FF EF FE 9 C F $68 B 1152081 B 063626 C 72642$

\section{Figure 6: Received Packet}

From the Z-Wave basics, the PHY layer frame is started with preamble pattern (the sequence of "1010" in binary) and then Start of Header Delimiter "00001111". By excluding the preamble pattern and the start of the header field, the rest data is expected to be the payload information. 


\section{University of Thi-Qar Journal Vol.12 No.3 SEP 2017 \\ Web Site: https://jutq.utq.edu.iq/index.php/main \\ Email: journal@jutq.utq.edu.iq}

Indeed, after invert (One's complement) the payload data (data after the start header field) the originally transmitted packet is obtained. At this point, it is important to define how long the packet is expected to be, in order to read it and drop the rest data. These steps to extract the wanted information from the received packet can be easily implemented by a simple code in $\mathrm{C}$ language during future design steps which have been already accomplished during this work.

\subsection{Sniffer Design with Code Composer Studio (CCS)}

Code Composer Studio (CCS) is an integrated development environment (IDE) for Texas Instruments (TI) microcontrollers and application processors. It is a Windows and Linux application used to develop and debug embedded applications [11].

The second step of the Sniffer design is implemented by the CCS. The Design in this level is represented by the code that was written in the $\mathrm{C}$ language. The registers configuration from the SmartRF Studio is used, as well as the real Sniffer function, Wake on Radio (WOR) feature is initiated, and registers that govern the duty cycle of WOR mode have been set.

\subsubsection{Software Code Design}

Figure 7, illustrate the Sniffer code in terms of the flow chart, in which the main design steps have been introduced. In this code design, the initiation of the clock system, peripherals, and their interfaces is done in the main function. As soon as the Sniff Mode is activated, the Sniffer source code started to be executing; the SPI interface to the transceiver is going to be initiated, then this followed by the registers configuration, and activation of the Sniff Mode. The Transceiver can enter a low power mode with an infinitely loop or implement another piece of code and look for new packets with defined time interval. However, termination condition for this mode can be defined to enter another mode or return to the main menu. 
Web Site: https://jutq.utq.edu.iq/index.php/main

Email: journal@jutq.utq.edu.iq

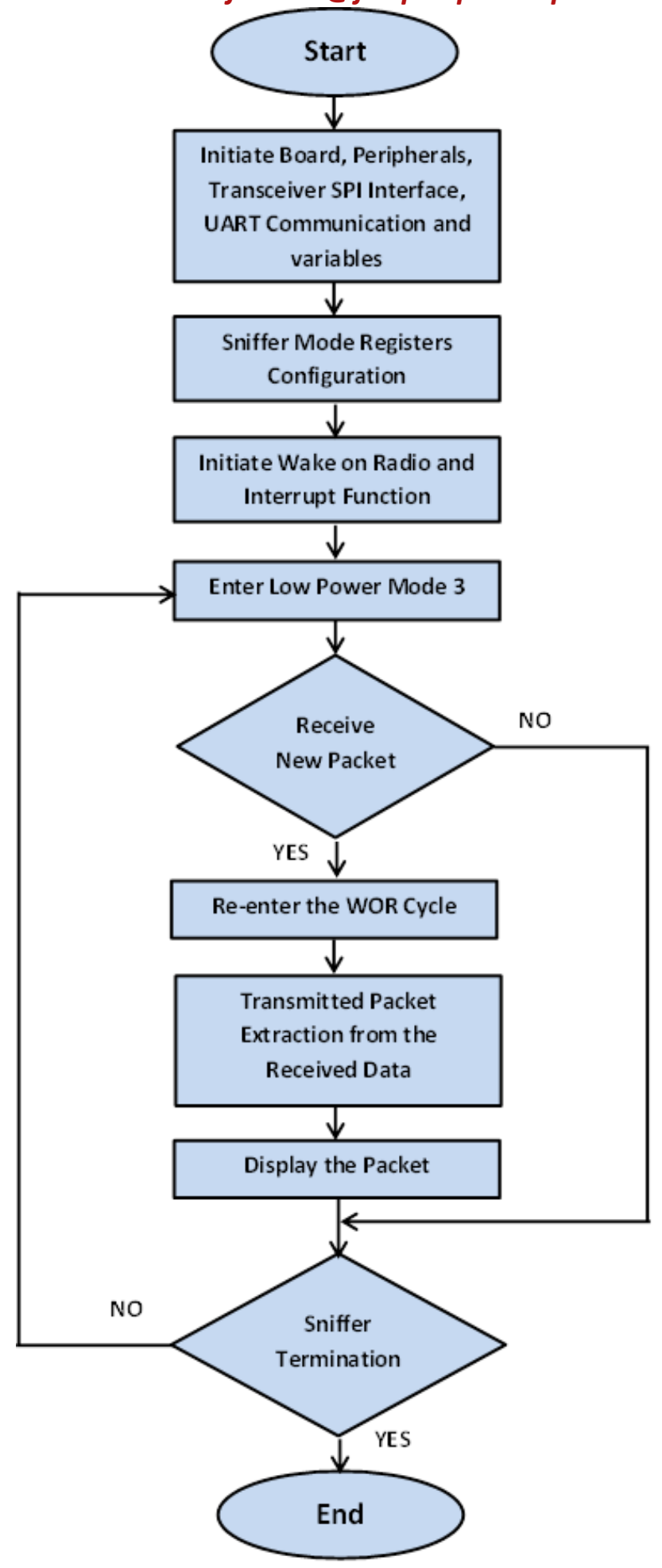




\section{University of Thi-Qar Journal Vol.12 No.3 SEP 2017 \\ Web Site: https://jutq.utq.edu.iq/index.php/main \\ Email: journal@jutq.utq.edu.iq \\ Figure 7: Code design flow chart}

\subsubsection{Hardware Initialization}

As the first step in the code, it is obligatory to initiate the clock system, peripherals (i.e. LCD display, Buttons, LEDs, etc.) which are used during the code implementation, variables, as well as the transceiver SPI interface. LCD display also accessed by SPI interface, which is shared with the SPI Flash, therefore it is important to disable the communication with the flash and initiate it with the LCD. Table 3 shows the functions that have been used in this section.

Table 3: Initiation Functions

\begin{tabular}{|l|l|}
\hline Purpose & Code Function \\
\hline $\begin{array}{l}\text { Select 32-kHz watch crystal } \\
\text { oscillator (XT1 mode) }\end{array}$ & halMcuStartXT1(); \\
\hline Initiate the MCU with clock speed & $\begin{array}{l}\text { halMcuSetSystemClock } \\
\text { (systemClockSpeed) }\end{array}$ \\
\hline Initiate the LEDs and turn them off & halLedInit(); \\
\hline $\begin{array}{l}\text { Initiate the buttons and enable their } \\
\text { timer }\end{array}$ & $\begin{array}{l}\text { halButtonsInit(); } \\
\text { halButtonsInterruptEnable(); }\end{array}$ \\
\hline $\begin{array}{l}\text { Initiate the LCD and clear the } \\
\text { screen }\end{array}$ & $\begin{array}{l}\text { halLcdInit(); } \\
\text { halLcdClear(0); }\end{array}$ \\
\hline $\begin{array}{l}\text { Initiate the transceiver RF SPI } \\
\text { interface }\end{array}$ & $\begin{array}{l}\text { trxRfSpiInterfaceInit } \\
\text { (systemClockSpeed); }\end{array}$ \\
\hline Initiate the UART communication & UARTInit(); \\
\hline
\end{tabular}

\subsubsection{Registers Configuration}

The special function has been used to configure the transceiver with the register values required for the sniffer function. Registers values are defined as a constant table, each register has its own memory address which is 


\section{University of Thi-Qar Journal Vol.12 No.3 SEP 2017 \\ Web Site: https://jutq.utq.edu.iq/index.php/main Email: journal@jutq.utq.edu.iq}

defined in one of the header files. The function will read this address and write the register value to it.

\subsubsection{Initiate the Wake-On-Radio Feature}

Initiate the WOR feature includes calling the interrupt service routine which is responsible for configuring the registers that govern the sniffer function. Table 4 shows the functions that have been used to connect the RX interrupt service routine to the interrupt function, and enter a WOR cycle including interrupt clear flag and enable transceiver interrupt. By these two functions, the Radio switched from idle to WOR mode. Table 5 shows the registers values and the corresponding function.

Table 4: Connect ISR to interrupt and enter a WOR cycle functions

\begin{tabular}{|l|l|}
\hline Purpose & Code Function \\
\hline $\begin{array}{l}\text { Connect ISR function to interrupt from } \\
\text { GDO0 (P1.7) }\end{array}$ & trxIsrConnect(\&radioRXISR); \\
\hline TRX from Idle to WOR & trxIdleWor( ); \\
\hline
\end{tabular}

Table 5: Initiate Wake-On-Radio registers setting

\begin{tabular}{|l|l|l|}
\hline Register & Value & Function \\
\hline AGC_CS_THR & 0x19 & Set AGC carrier sense threshold \\
\hline AGC_CFG0 & 0xCF & Set RSSI valid count to minimum: 2 \\
\hline AGC_CFG1 & 0xA9 & $\begin{array}{l}\text { Set AGC window size to 8 samples } \\
\text { Set AGC settle wait time to 24 } \\
\text { SAMPLES }\end{array}$ \\
\hline SETTLING_CFG & $0 \times 03$ & Turning off the Auto-Calibration \\
\hline WOR_CFG1 & 0x08 & $\begin{array}{l}\text { Setting WOR mode to } \\
\text { NORMAL_MODE \& WOR timer } \\
\text { resolution to HIGH_RESOLUTION }\end{array}$ \\
\hline
\end{tabular}


University of Thi-Qar Journal Vol.12 No.3 SEP 2017

Web Site: https://jutq.utq.edu.iq/index.php/main

Email: journal@jutq.utq.edu.iq

\begin{tabular}{|l|l|l|}
\hline WOR_EVENT0_MSB & $0 \times 02$ & \multirow{2}{*}{ Setting Event0 timeout, to $20 \mathrm{~ms}$} \\
\hline WOR_EVENT0_LSB & 0x08 & \\
\hline WOR_CFG1 & 0x0E & Setting Event1 timeout, to 1ms \\
\hline \multirow{2}{*}{ WOR_CFG0 } & $0 \times 24$ & $\begin{array}{l}\text { Enable RC calibration to send } \\
\text { calibration storb }\end{array}$ \\
\cline { 2 - 3 } & $0 \times 20$ & Disable calibration \\
\hline RFEND_CFG1 & $0 \times 0 \mathrm{E}$ & Setting RX timeout to never \\
\hline RFEND_CFG0 & 0x09 & Setting RX termination of RSSI \\
\hline
\end{tabular}

This followed by updating the LCD display indicating that the transceiver entered the new mode.

\subsubsection{Receiving Packets}

After entering the WOR cycle the transceivers is ready to receive new packets. As soon as a new packet has been received the data read from the FIFO and stored in a matrix buffer.

Re-entering the WOR mode to receive new packet is done by using the same function mentioned before for this purpose. However, this implies the use of multi-dimensions array to store the received packet(s) that may be received during the evaluation and displaying the previous one. The received packet has to be prepared to extract the originally transmitted information by the Z-Wave device, according to the steps defined in section 4.2.1. To monitor the data that have been received there is more than one possibility. One option could use the LCD display which is available with CC1125 transceiver board. Another option is to use UART serial communication with PC to monitor the data one the PC, using a software application like Putty.

\section{Conclusion}

In this research work, the Z-Wave Sniffer has been designed and implemented on CC1125 Transceiver. The design done in two steps; first, the SmartRF used to find the right registers setting then these registers values 


\section{University of Thi-Qar Journal Vol.12 No.3 SEP 2017 \\ Web Site: https://jutq.utq.edu.iq/index.php/main \\ Email: journal@jutq.utq.edu.iq}

exported to be used in the Sniff Mode configuration using the Code Composer Studio.

One of the important aspects of the design is choosing the sync word same as the preamble of the packet to be received, thereby the packet will be received with the preamble pattern. Received packet entered in a special function to extract the originally transmitted information from it. This function includes scanning the received binary sequence looking for the starting header delamination " 00001111 ", then exclude the data before it (the preamble pattern). The rest data will represent the original transmitter information after doing the one's complement. The received message has been passed to a computer where it can be analyzed and understand the message transmitter status.

\section{Future Work}

As future work, the same research principle can be considered to design a Sniffer for other smart home protocols. The same design can be used to sniff multi packets with different data rates simultaneously; this can be implemented by more than one way, like oversampling with high data rate, or switching between two registers configuration by using timer interrupt; however, this required accurate timing calculation which depends on the preamble length of the transmitted packets.

\section{References}

[1] Huo, L. (2014). A Comprehensive Study of Passive Wake-up Radio in Wireless Sensor Networks. Delft University of Technology.

[2] Mendes, T., Godina, R., Rodrigues, E., Matias, J., \& Catalão, J. (2015). Smart Home Communication Technologies and Applications: Wireless Protocol Assessment for Home Area Network Resources. Energies, 8(7), 7279-7311. https://doi.org/10.3390/en8077279

[3] Texas Instruments. SmartRF Transceiver Evaluation Board "TrxEB" User's Guide. Retrieved March 15, 2014, from http://www.ti.com/lit/ug/swru294a/swru294a.pdf

[4] Mendes, T., Godina, R., Rodrigues, E., Matias, J., \& Catalão, J. (2016). Smart Home Communication Technologies and Applications: Wireless Protocol Assessment for Home Area Network Resources. Energies, 8(7), 7279-7311. https://doi.org/10.3390/en8077279 


\section{University of Thi-Qar Journal Vol.12 No.3 SEP 2017 \\ Web Site: https://jutq.utq.edu.iq/index.php/main \\ Email: journal@jutq.utq.edu.iq}

[5] Mendes, T., Godina, R., Rodrigues, E., Matias, J., \& Catalão, J. (2015). Smart Home Communication Technologies and Applications: Wireless Protocol Assessment for Home Area Network Resources. Energies, 8(7), 7279-7311. https://doi.org/10.3390/en8077279

[6] Texas Instruments. Ultra-High Performance RF Narrowband Transceiver (CC1125). Retrieved March 15, 2014, from http://www.ti.com/lit/ds/swrs120a/swrs120a.pdf

[7] Macii, D., Ageev, A., \& Somov, A. (2009). Power consumption reduction in wireless sensor networks through optimal synchronization. 2009 IEEE Intrumentation and Measurement Technology Conference, I2MTC 2009, 1352-1356. https://doi.org/10.1109/IMTC.2009.5168665

[8] Texas Instruments. CC112X/CC1175 Low-Power High Performance Sub-1 GHz RF Transceivers/Transmitter. Retrieved March 15, 2014, from http://www.ti.com/lit/ug/swru295c/swru295c.pdf

[9] Kumberg, T., Schink, M., Reindl, L. M., \& Schindelhauer, C. (2017). TROME: A simple and energy efficient tree routing protocol for low-power wake-up receivers. Ad Hoc Networks. https://doi.org/10.1016/j.adhoc.2017.02.003

[10] Kumberg, T., Schink, M., Reindl, L. M., \& Schindelhauer, C. (2017). TROME: A simple and energy efficient tree routing protocol for low-power wake-up receivers. Ad Hoc Networks. https://doi.org/10.1016/j.adhoc.2017.02.003

[11] Texas Instruments. Code Composer Studio IDE. Retrieved March 15, 2014, from http://www.ti.com/lit/ml/sprue40/sprue40.pdf 